\section{To: (Receiving Organization) NHC Process Development}

5. Proj./Prog./Dept./Div.:

TWRS

8. Originator Remarks: Approval/release of attached Test Plan is requested.
3. From: (Originating Organization) NHC Process Chemistry

6. Design Authority/ Design Agent/Cog. Engr.:

D. L. Herting

4. Related EDT No.:
NA

7. Purchase order No.: NA

9. Equip./Component No.: NA

10. System/Bldg./Facility: 222-5 Laboratory

12. Major Assm. Dwg. No.:

NA

13. Permit/Permit Application No.: NA

14. Requi red Response Date: March 1, 1999

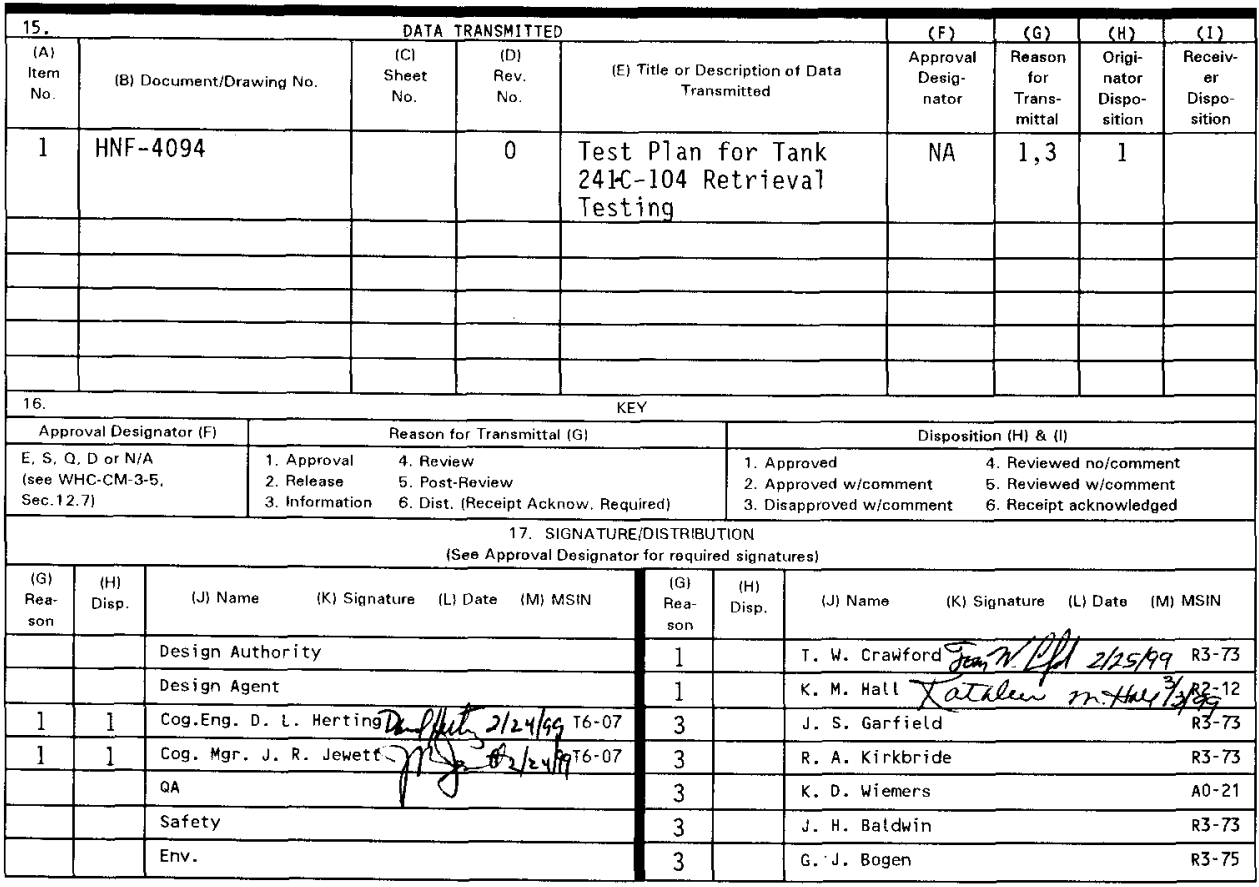

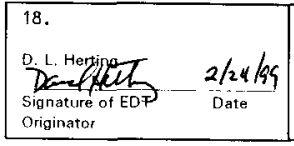

19.

Lom. crawipre 0

2/25/\% for Receiving Organization
20 .

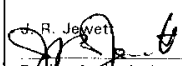
Dffin A cognizanthanage
21. DOE APPROVAL (if required) Ctrl. No.

[] Approved

[] Approved w/comments

[] Disapproved w/comments

BD-7400-172-2(05/96) GEF097 


\title{
Test Plan for Tank 241-C-104 Retrieval Testing
}

\author{
D. L. Herting, M. A. Beck, and J. F. O'Rourke \\ Numatec Hanford Corporation, Richland, WA 99352 \\ U.S. Department of Energy Contract DE-AC06-96RL 13200 \\ $\begin{array}{lll}\text { EDT/ECN: } & 625407 & \text { UC: } 2030 \\ \text { Org Code: } & 82100 & \text { Charge Code: } 106434 \\ \text { B\&R Code: } & \text { EW3130010 } & \text { Total Pages: } 11\end{array}$
}

Key Words: high-level waste, privatization, waste feed delivery, dilution, sludge, settling rate, viscosity, particle size

Abstract: Tank 241-C-104 has been identified as one of the first tanks to be retrieved for high-level waste pretreatment and immobilization. Retrieval of the tank waste will require dilution. Laboratory tests are needed to determine the amount of dilution required for safe retrieval and transfer of feed. The proposed laboratory tests are described in this document.

* Haake is a registered trademark of Haake Medingen GMBH.

TRADEMARK DISCLAIMER. Reference herein to any specific commercial product, process, or service by trade name, trademark, manufacturer, or otherwise, does not necessarily constitute or imply its endorsement, recommendation, or favoring by the United States Government or any agency thereof or its contractors or subcontractors.

Printed in the United States of America. To obtain copies of this document, contact: Document Control Services, P.O. Box 950, Mailstop H6-08, Richland WA 99352, Phone (509) 372-2420;

Fax (509) 376-4989.

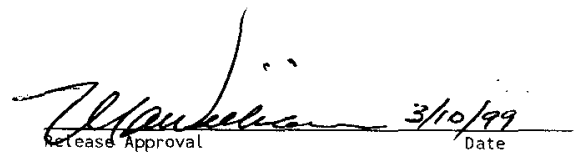

Approved for Public Release 


\section{CONTENTS}

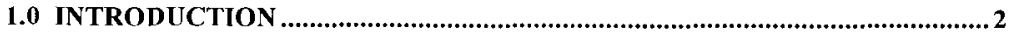

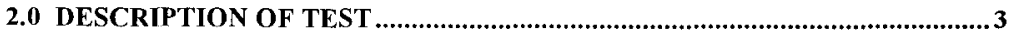

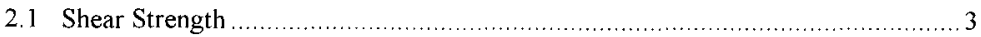

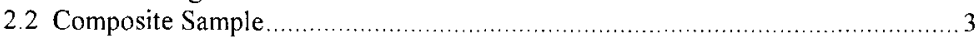

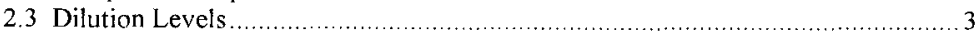

2.4 Density and Settling Rate Measurements ............................................... 4

2.5 Viscosity and Particle Size Distribution ............................................... 4

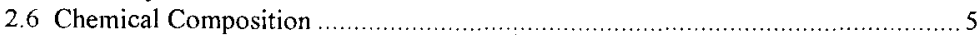

2.7 Sludge Washing and Caustic Leaching ........................................................ 5

2.8 Sludge Composition as a Function of Settling ......................................... 5

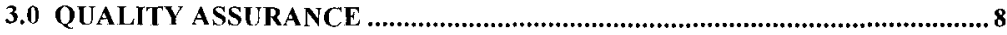

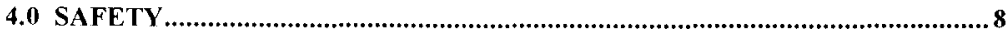

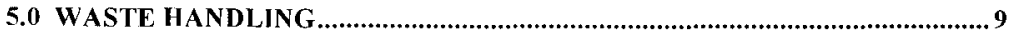

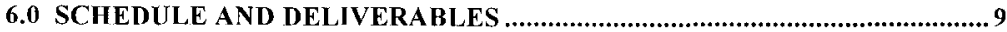

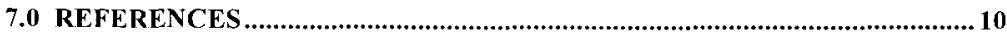

\section{TABLES}

Table 1. Liquid Phase Analyses for Composite Sample at Target Dilution ............. 6

Table 2. Centrifuged Solids Analyses for Composite Sample at Target Dilution ........ 7 


\subsection{INTRODUCTION}

Tank 241-C-104 has been selected as a Phase I source tank for High Level Waste sludge feed for vitrification. The $530 \mathrm{kgal}$ tank contains $295 \mathrm{kgal}$ of sludge, which will be sluiced to the double-shell tank 241-AY-102. From there, smaller batches of sludge (100 kgal) will be delivered to the vitrification contractor

Rheological data are needed to develop engineering plans for the sluicing and pumping operations. Chemical composition data are needed to verify the ability to meet contract feed specifications. Other physical data are needed to support computational fluid dynamics modeling of sludge mobilization using mixer pumps.

The laboratory tests outlined in this Test Plan are designed to obtain all these types of data. The tests are based on test requirements established by Process Development (Nguyen 1999a).

Tank C-104 was core-sampled twice in July, 1996, and three times in August, 1998. The 1996 core samples were subjected to a typical suite of analytical measurements, which are reported in the Tank Characterization Report (Baldwin 1997). They show marked vertical inhomogeneity in color, texture, and chemical composition. Concentrations of major elements like aluminum, iron, and zirconium vary by an order of magnitude or more from one sharply-defined layer to another within the waste.

Core 247 from the 1998 sampling event was reserved for the process testing described in this Test Plan. Five segments were taken, representing the full depth of the sludge in the tank. Based on the percent recovery of the samples, core 247 was judged to be a better representation of the tank inventory than the 1996 core samples. Based on the physical appearance of the samples, segments $1,2,4$, and 5 were divided into half-segment fractions. Segment 3 was divided into four fractions. All of the fractions have been stored undisturbed in sample jars since early September, 1998. All of the yield strength measurements will be performed before any sample mixing takes place. Other testing will be done on composite samples as described in detail later in the Test Plan. 


\subsection{DESCRIPTION OF TEST}

\subsection{Shear Strength}

A Haake M5 viscometer will be used for the rheological measurements. Use of the viscometer is governed by procedure number LA-519-105. For shear strength, the Haake M5 will be equipped with an FL-1000 shear vane. To determine the shear strength of a material, the FL-1000 is inserted into a sample and rotated at a slow constant speed. Shear strength is defined as the force required to cause shear failure in the material.

Shear strength measurements will be performed on all twelve sample jars (half- and quarter-segment samples) before any of the samples are disturbed. All measurements will be done at ambient hotcell temperature (typically around $28^{\circ} \mathrm{C}$ ).

\subsection{Composite Sample}

All other testing (besides shear strength) will be performed on aliquots taken from a composite sample. To prepare the composite, each half-segment or quarter-segment sample jar will be mixed. Then equal fractions by weight from each half-segment sample and half as much from each quarter-segment sample will be combined into a $500 \mathrm{~mL}$ jar. The composite sample will then be re-mixed. Two identical composite jars will be needed for the testing, each containing about $400 \mathrm{~mL}$ of sample. Approximately $75 \%$ of the sample from each of the 12 jars will be used, and the remaining $25 \%$ will be left in the original jars for other potential characterization needs or process testing needs.

\subsection{Dilution Levels}

Retrieval of the sludge from tank C-104 will require dilution to transport the sludge to tank AY-102. The diluent used for the laboratory tests will be inhibited water $(0.01 \mathrm{M}$ in $\mathrm{NaOH}$ and $0.01 \mathrm{M}$ in $\mathrm{NaNO}_{2}$ ).

Process Development has assigned a "target dilution" for the transport of C-104 sludge, such that the diluted sludge will contain 100 grams of solids per liter of diluted sludge $(100 \mathrm{~g} / \mathrm{L})$. All chemical composition data, water wash testing, and caustic wash testing will be done on sludge at the target dilution level. Physical measurements (density, settling rate, viscosity, particle size distribution) will be done on sludge at the target dilution level and at one dilution level on either side of the target $(60 \mathrm{~g} / \mathrm{L}$ and $140 \mathrm{~g} / \mathrm{L})$. The amount of diluent required to reach the target dilution will be calculated from the existing characterization data for the sludge. The actual dilution levels achieved will be measured and reported. 


\subsection{Density and Settling Rate Measurements}

Density measurements will be provided for bulk sample, liquid phase, and settled solids for each of the three dilution levels of the composite sample. These measurements will be derived from the samples used for settling rate tests. The bulk density of the undiluted sludge can be calculated from the bulk density of the diluted samples.

For each test, $100 \mathrm{~mL}$ of diluted sludge will be poured into a tared graduated cylinder, and allowed to settle for at least one week. The position of the interface between settled solids and supernatant liquid will be recorded as often as there is a significant change, which may be hourly near the beginning of the test and daily near the end of the test. At the conclusion of the test, a sample of the supernatant liquid will be analyzed for density by procedure LA-510-112

The bulk density is derived from the total weight and volume of the diluted sludge sample in the $100 \mathrm{~mL}$ graduated cylinder. The liquid phase density, determined by analysis, is used to calculate the weight of the supernatant liquid in the graduated cylinder, which gives the weight of the settled solids by difference. The settled solids density is calculated from the measured volume and calculated weight of the settled solids.

\subsection{Viscosity and Particle Size Distribution}

Viscosity and particle size distribution measurements will be made on the undiluted composite sample and at each of the three dilution levels. The viscosity will also be measured for supernatant liquid from the diluted sludge at the target dilution. Particle size distribution will also be measured on the sludge fractions partitioned by relative settling rates (see Section 2.8)

For viscosity measurements, the Haake M5 viscometer will be equipped with the MV-1 coaxial cylinder sensor system. Viscosity is calculated by measuring the torque on the inner cylinder as a function of its rotational speed. The MV-1 sensor is water-jacketed to allow precise temperature control. Viscosity measurements will be made at ambient hotcell temperature, and at 45 and $65^{\circ} \mathrm{C}$.

A Horiba LA-910 Particle Size Analyzer will be used for the particle size distribution analyses. The Horiba LA-910 uses laser diffraction to determine the volume distribution of particles with sizes ranging from $0.02 \mu \mathrm{m}$ to $1020 \mu \mathrm{m}$. Laboratory technology procedure LT-519-105 will be followed for the particle size distribution analyses. The particles are diluted with enough supernatant liquid to make a well-separated suspension. All measurements will be made at ambient room temperature (typically around $25^{\circ} \mathrm{C}$ ). 


\subsection{Chemical Composition}

Duplicate samples of diluted sludge at the target dilution will be separated by centrifugation at ambient temperature into supernatant liquid and centrifuged solids fractions. Centrifuged samples will be examined to determine whether they contain any floating (or otherwise separate) organic layer. Supernatant liquid samples will be analyzed for the "envelope B" list of analytes shown in Table 1 (Nguyen 1999b). The solids will be analyzed according to the "envelope D" list shown in Table 2 (Nguyen 1999a).

\subsection{Sludge Washing and Caustic Leaching}

Duplicate samples of diluted sludge (at the target dilution) will be washed three times with inhibited water at a $1: 1$ volume ratio of water to diluted sludge. The washes will be done for eight hours each at 80 to $90^{\circ} \mathrm{C}$ and ambient pressure. The final slurry will be centrifuged. The solids will be analyzed for the following subset of the analytes in Table 2: TGA (direct sample), ICP (after acid digest), and ${ }^{99} \mathrm{Tc}$ by liquid scintillation (after fusion).

Two more samples of diluted sludge at the target dilution will be washed three times with inhibited water as above, then leached once with $3 \mathrm{M} \mathrm{NaOH}$ (same volume ratio) for eight hours at 80 to $90^{\circ} \mathrm{C}$. The leach step will be followed by two more water washes, again for eight hours at 80 to $90^{\circ} \mathrm{C}$. The centrifuged solids will be analyzed for the same subset as the washed solids above.

Liquid phase samples from the wash and leach tests are not analyzed.

\subsection{Sludge Composition as a Function of Settling}

Duplicate samples of sludge at the target dilution level will be poured into $100 \mathrm{~mL}$ graduated cylinders and allowed to settle. When approximately one-third of the solids have settled to the bottom of the cylinder, the remaining slurry (the unsettled portion) is transferred to new graduated cylinders and allowed to settle. When approximately onehalf of the remaining solids (the second one-third of the original solids) have settled, the remaining slurry is decanted into centrifuge cones. The first and second fractions are also transferred from the graduated cylinders to centrifuge cones.

The original slurry is now divided into three fractions (in duplicate), with the fractions differentiated by the settling rates of the solids. All of the cones are centrifuged, and the solids are analyzed for the following: TGA and particle size distribution (direct sample); and ICP/AES, GEA, and AT/TB (after fusion) 
Table 1. Liquid Phase Analyses ${ }^{1}$ for Composite Sample at Target Dilution

\begin{tabular}{|c|c|c|}
\hline Procedure & Method & Analytes \\
\hline$L A-505-161$ & $\mathrm{ICP} / \mathrm{AES}$ & $\begin{array}{c}\mathrm{Ag}, \mathrm{Al}, \mathrm{As}, \mathrm{B}, \mathrm{Ba}, \mathrm{Be}, \mathrm{Bi}, \mathrm{Ca}, \mathrm{Cd}, \mathrm{Ce}, \mathrm{Co}, \mathrm{Cr}, \\
\mathrm{Cu}, \mathrm{Fe}, \mathrm{K}, \mathrm{La}, \mathrm{Li}, \mathrm{Mg}, \mathrm{Mn}, \mathrm{Mo}, \mathrm{Na}, \mathrm{Nd}, \mathrm{Ni}, \mathrm{P} \\
\mathrm{Pb}, \mathrm{Pd}, \mathrm{Pr}, \mathrm{Rb}, \mathrm{Rh}, \mathrm{Ru}, \mathrm{S}, \mathrm{Sb}, \mathrm{Se}, \mathrm{Si}, \mathrm{Sm}, \mathrm{Sr}, \mathrm{Ta} \\
\text { Te, Th, Ti, Tl, U, V, W, Y, Zn, Zr }\end{array}$ \\
\hline LA-533-105 & IC & $\mathrm{Br}^{-}, \mathrm{Cl}^{-}, \mathrm{F}^{-}, \mathrm{NO}_{2}^{-}, \mathrm{NO}_{3}^{-}, \mathrm{C}_{2} \mathrm{O}_{4}{ }^{2-}, \mathrm{PO}_{4}{ }^{3-}, \mathrm{SO}_{4}{ }^{2-}$ \\
\hline LA-510- 112 & specific gravity & density \\
\hline LA-325-104 & CVAA & $\mathrm{Hg}$ \\
\hline LA-342-100 & $\begin{array}{l}\text { persulfate/ } \\
\text { combustion }\end{array}$ & TIC/TOC \\
\hline LA-212-106 & $\mathrm{pH}$ & $\mathrm{pH}$ \\
\hline LA-514-114 & TGA & $\% \mathrm{H}_{2} \mathrm{O}$ \\
\hline LA-211-102 & titration & $\mathrm{OH}^{*}$ \\
\hline LA-506-10] & $\mathrm{ICP} / \mathrm{MS}$ & $\begin{array}{c}{ }^{99} \mathrm{Tc},{ }^{126} \mathrm{Sn},{ }^{\text {Total }} \mathrm{Cs},{ }^{233 / 235} \mathrm{U},{ }^{237} \mathrm{~Np}, \\
{ }^{238 / 239 / 240 / 241 / 242} \mathrm{Pu},{ }^{243} \mathrm{Am}\end{array}$ \\
\hline LA-438-101 & $\begin{array}{c}\text { Liquid } \\
\text { Scintillation }\end{array}$ & ${ }^{99} \mathrm{Tc}$ \\
\hline LA-548-121 & GEA & ${ }^{137} \mathrm{Cs},{ }^{60} \mathrm{Co},{ }^{152 / 154 / 155} \mathrm{Eu},{ }^{125} \mathrm{Sb}$ \\
\hline LA-220-101 & $\begin{array}{l}\text { Separation } \& \\
\text { beta counting }\end{array}$ & ${ }^{90} \mathrm{Sr}$ \\
\hline LA-508-101 & $\begin{array}{l}\text { alpha/beta } \\
\text { counting }\end{array}$ & total alpha/total beta (AT/TB) \\
\hline
\end{tabular}

${ }^{1}$ Acronym definitions:

ICP/AES - inductively coupled plasma atomic emission spectroscopy

IC - ion chromatography

CVAA - cold vapor atomic absorption

TGA - thermogravimetric analysis

ICP/MS - inductively coupled plasma mass spectroscopy

AEA - alpha energy analysis

GEA - gamma energy analysis 
Table 2. Centrifuged Solids Analyses for Composite Sample at Target Dilution

\begin{tabular}{|c|c|c|c|}
\hline Procedure & Method & Prep & Analytes \\
\hline LA-505-161 & ICP/AES & $\begin{array}{c}\text { acid } \\
\text { digest }\end{array}$ & $\begin{array}{c}\mathrm{Ag}, \mathrm{Al}, \mathrm{As}, \mathrm{B}, \mathrm{Ba}, \mathrm{Be}, \mathrm{Bi}, \mathrm{Ca}, \mathrm{Cd}, \mathrm{Ce}, \mathrm{Co}, \mathrm{Cr} \\
\mathrm{Cu}, \mathrm{Fe}, \mathrm{K}, \mathrm{La}, \mathrm{Li}, \mathrm{Mg}, \mathrm{Mn}, \mathrm{Mo}, \mathrm{Na}, \mathrm{Nd}, \mathrm{Ni}, \mathrm{P}, \\
\mathrm{Pb}, \mathrm{Pd}, \mathrm{Pr}, \mathrm{Rb}, \mathrm{Rh}, \mathrm{Ru}, \mathrm{S}, \mathrm{Sb}, \mathrm{Se}, \mathrm{Si}, \mathrm{Sm}, \mathrm{Sr} \\
\text { Ta, Te, Th, Ti, Tl, U, V, W, Y, Zn, Zr }\end{array}$ \\
\hline LA-505-161 & ICP/AES & fusion & same as above \\
\hline LA-533-105 & IC & $\begin{array}{l}\text { water } \\
\text { digest }\end{array}$ & $\mathrm{Br}^{-}, \mathrm{Cl}^{-}, \mathrm{F}^{*}, \mathrm{NO}_{2}^{-}, \mathrm{NO}_{3}{ }^{-}, \mathrm{C}_{2} \mathrm{O}_{4}{ }^{2-}, \mathrm{PO}_{4}{ }^{3-}, \mathrm{SO}_{4}{ }^{2-}$ \\
\hline LA-325-104 & CVAA & direct & $\mathrm{Hg}$ \\
\hline LA-342-100 & $\begin{array}{l}\text { persulfate/ } \\
\text { combustion }\end{array}$ & direct & TIC/TOC \\
\hline LA-514-114 & TGA & direct & $\% \mathrm{H}_{2} \mathrm{O}$ \\
\hline LA-695-102 & colorimetry & direct & $\mathrm{CN}^{-}$ \\
\hline LA-211-102 & titration & $\begin{array}{l}\text { water } \\
\text { digest }\end{array}$ & $\mathrm{OH}^{-}$ \\
\hline LA-631-00I & $\begin{array}{l}\text { ion selective } \\
\text { electrode }\end{array}$ & $\begin{array}{l}\text { water } \\
\text { digest }\end{array}$ & $\mathrm{NH}_{3}$ \\
\hline LA-506-101 & ICP/MS & fusion & $\begin{array}{c}{ }^{90} \mathrm{Tc},{ }_{238 / 239 / 240 / 241 / 242}^{126} \mathrm{Su},{ }^{\text {Total }} \mathrm{Cs},{ }^{233} \mathrm{Am},{ }^{237} \mathrm{~Np}, \\
\end{array}$ \\
\hline LA-953-104 & $\begin{array}{c}\text { Separation/ } \\
\text { AEA }\end{array}$ & fusion & ${ }^{241} \mathrm{Am},{ }^{243 / 244} \mathrm{Cm}$ \\
\hline LA-438-101 & $\begin{array}{c}\text { Liquid } \\
\text { Scintillation }\end{array}$ & fusion & ${ }^{99} \mathrm{Tc}$ \\
\hline LA-548-121 & GEA & fusion & ${ }^{137} \mathrm{Cs},{ }^{60} \mathrm{Co},{ }^{152 / 154 / 155} \mathrm{Eu},{ }^{125} \mathrm{Sb}$ \\
\hline LA-218-114 & $\begin{array}{l}\text { liquid } \\
\text { scintillation }\end{array}$ & fusion & ${ }^{3} \mathrm{H}$ \\
\hline LA-348-104 & $\begin{array}{l}\text { liquid } \\
\text { scintillation }\end{array}$ & fusion & ${ }^{14} \mathrm{C}$ \\
\hline LA-220-101 & $\begin{array}{l}\text { Separation \& } \\
\text { beta counting }\end{array}$ & fusion & ${ }^{90} \mathrm{Sr}$ \\
\hline LA-378-103 & separation GEA & fusion & ${ }^{129} 1$ \\
\hline LA-508-10I & $\begin{array}{l}\text { alpha/beta } \\
\text { counting }\end{array}$ & fusion & total alpha/total beta (AT/TB) \\
\hline
\end{tabular}




\subsection{QUALITY ASSURANCE}

Based on the requirements in "Review and Approval of Documents", HNF-PRO-233, this Test Plan is assigned Approval Designator N/A. Approval signatures are required from the author, immediate manager, and customer.

All testing will follow the "Process Chemistry and Statistics Quality Assurance Plan", WHC-SD-CP-QAPP-018, Rev. 0 (Meznarich 1996). Specific laboratory instructions will be reviewed and approved by Process Chemistry management, 222-S Radiological Control, and 222-S Environmental prior to initiation of testing. The instructions will be recorded in a controlled laboratory notebook before work begins; observations and data will be recorded as the work is done.

In addition to the duplicate testing described in Section 2, standard laboratory quality control protocols will apply to the analytical work. These include (wherever appropriate) one duplicate, one spike, one standard, and one blank per batch of samples analyzed.

\subsection{SAFETY}

All of the safety requirements that apply to this Test Plan are described in "Development of Instrumentation, Methods and Performance of Process Testing", Hanford Analytical Services Laboratory Operating Procedure LO-140-100, Rev. C-0, released July 28, 1998. 


\subsection{WASTE HANDLING}

Three waste streams are expected to be generated from this test program. Stream \#1 is the waste resulting from analysis of samples. Each waste generated from these routine analyses will be handled in accordance with the instructions in the procedures for the respective analyses.

Stream \#2 is the used and left-over tank waste material. This material, expected to be less than $1 \mathrm{~kg}$, will be discarded to the $219-\mathrm{S}$ Building tanks via a hotcell drain, per procedure LO-100-107, "Cubicle Housekeeping, Waste Disposal, and Management", and in compliance with 222-S Laboratory Standing Order 98-016, Rev. 1, "Accounting for Solids Generated from. Routine Work and Sample Disposal Activities in 222-S Hotcells", December 31, 1998 .

Stream \#3 is the solid hotcell waste consisting of used centrifuge cones, used sample vials, and used plastic syringes. This waste will be rinsed with water, loaded into waste cans, removed from the hotcell, and disposed of according to LO-100-151.

Other than the waste streams just described, there will be no accumulating of hazardous waste. Therefore, no Waste Stream Fact Sheet or Waste Compatibility Assessment documentation will be required

\subsection{SCHEDULE AND DELIVERABLES}

This Test Plan is scheduled to be issued by March 1, 1999. Management approval for the specific laboratory instructions will be obtained by March 15, 1999. Laboratory work will commence by March 22, 1999.

A complete report of the test results will be issued in the form of a draft supporting document by September 1, 1999. Informal interim status reports will be issued to the customer via e-mail on a weekly or biweekly basis. 


\subsection{REFERENCES}

Baldwin, J. H. (1997), Tank Characterization Report for Single-Shell Tank 241-C-104, HNF-SD-WM-ER-679, Rev. 0, Lockheed Martin Hanford Corporation, Richland, Washington.

Meznarich, H. K. (1996), Process Chemistry \& Statistics Quality Assurance Plan, WHC-SD-CP-QAPP-018, Rev. 0, Westinghouse Hanford Company, Richland, Washington.

Nguyen, D. M. (1999a), Data Quality Objectives for TWRS Privatization Phase 1: Confirm Tank T is an Appropriale Feed Source for High-Level Waste Feed Batch $X$, HNF-1558, Rev. 1, PSDQO-02, Lockheed Martin Hanford Corporation, Richland, Washington.

Nguyen, D. M. (1999b), Data Qnality ()bjectives for TWRS Privatization Phase 1: Confirm Tank T is an Appropriate Feed Sonce for Low-Activity Waste Feed Batch X, HNF-1796, Rev. 2, PSDQO-01, Lockheed Martin Hanford Corporation, Richland, Washington. 